\title{
Museums of Pioneers of Medicine and Nursing in London
}

Key words: medical museums, London, university museums, history of medicine, history of nursing, Alexander Fleming, Florence Nightingale

London museums are huge. Large spaces filled with the most important works of world art and exhibits collected on the islands for hundreds of years are often arranged in a modern way to interest both adults and younger visitors. ${ }^{1}$ The eyes of medical historians also look at Great Britain, because the roots of medical and pharmaceutical museums can be found there. In the history of medicine, London and the whole country played a huge role. Great Britain is a country great people of medicine like John Hunter, John Langdon Down, Henry Wellcome, Alexander Fleming, Robert Edwards, Patrick Steptoe and others. London and its surrounding is reach in medical museums. Currently, London's medical museums are associated in a group called London Museums of Health and Medicine. This group includes 26 museums showing broadly understood history of medicine and pharmacy, there are also museums of royal scientific societies, museums of hospitals, museums of pioneers of British medicine and nursing as well as university museums.

These museums show diverse specificity of history of medicine - from herbs, heart surgery and helicopter emergency services, to pharmacies, false teeth and forensic pathology, they provide

${ }^{1}$ http://natemat.pl/95199,najciekawsze-muzea-w-londynie [access on: 15.11.2017]. 
remarkable insights into humanity's age-long campaign for good health. ${ }^{2}$

The group of London Museums of Health and Medicine includes: Alexander Fleming Laboratory Museum, Anesthesia Heritage Center, Bart's Pathology Museum, British Dental Association Museum, Bethlem Museum of the Mind, British Red Cross Museum and Archives, Chelsea Physic Garden, College of Optometrists, Florence Nightingale Museum, Freud Museum London, Foundling Museum, Hunterian Museum, ${ }^{3}$ Royal College of Surgeons, Langdon Down Museum of Learning Disability, Museum of the Order of St. John, Old Operating Theatre \& Herb Garret, Royal Botanic Gardens, Kew, Royal College of Nursering Library \& Heritage Centre, Royal College of Obstetricians and Gynaecologists, Royal College of Physicians Museum, Royal London Hospital Museum, Royal Pharmaceutical Society Museum, Royal Society of Medicine, Science Museum, St Bartholomew's Hospital Museum, Wellcome Collection, Worshipful Society of Apothecaries of London, Science Museum.

London Museums of Health and Medicine has its own website $\mathrm{http}: / /$ medicalmuseums.org/ and it published an information leaflet available in each museum belonging to the group.

All museums of the London Museums of Health and Medicine group are worth a visit because they show a variety of expositions, they are often situated in historical buildings, and a visit to them leaves an unforgettable impression. From the afore mentioned list of medical museums, I would like to describe two of them - museums of the pioneers of British medicine and nursing: Alexander Fleming Laboratory Museum and Florence Nightingale Museum.

\section{The birthplace of penicillin}

Alexander Fleming Laboratory Museum is located on the premises of St Mary's Hospital at Praed Street in London. It occupies three floors in the Clarence Memorial St. Mary's Hospital.

St. Mary's Hospital was founded in 1845 as a voluntary hospital for the sick poor of North-West London and admitted its first patients in 1851. Until 1948 it was completely self-governing and depended upon charitable support for its maintenance. It was planned as a teaching

\footnotetext{
${ }^{2} \mathrm{http}: / /$ medicalmuseums.org/ [access on: 15.11.2017].

3 About Hunterian Museum and Foundling Museum wrote: M. Grassmann, Dawna medycyna nad Tamiza. Szlakiem londyńskich muzeów medycznych, "Medycyna Nowożytna” 2014, nr 2, pp. 153-163.
} 
hospital from the beginning and in 1854 St. Mary's Hospitals Medicine School was founded. In 1948 St. Mary's became part of the National Health Service and in 1993 became a NHS Trust.

Alexander Fleming Laboratory Museum was opened on September 21, 1993. The museum's director is Kevin Brown. ${ }^{4}$ London museum of Alexander Fleming is a reconstruction of this outstanding researcher's laboratory. The museum shows the extraordinary story of the accidental discovery of a life - saving medicine which revolutionized medicine. Thanks to the groundbreaking discovery Fleming won the prestigious Nobel Award.

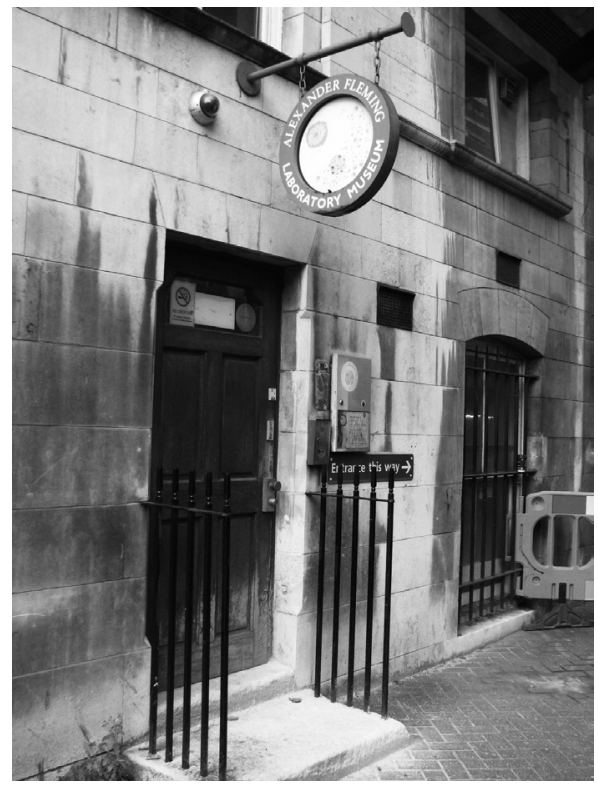

Fot. 1 The Alexander Fleming Laboratory Museum in St. Mary's Hospital

Source: photo: M. Piszczatowska.

The Museum offers a journey back in time to the days when there were no antibiotics to fight often lethal bacteria and then follow in the footsteps of Alexander Fleming on his road to the discovery that was to revolutionize medicine and affect the lives of every one of us. Alexander Fleming Laboratory Museum shows that the discovery of penicillin was perhaps one of the most significant events of the twentieth century and why it continues to play a vital part in the ever continuing fight against bacteria and disease.

${ }^{4}$ Kevin Brown - Trust Archivist and Alexander Fleming Laboratory Museum Curator at St Mary's NHS Trust, subsequently Imperial College Healthcare NHS Trust, since 1989, having set up the archives service for St Mary's Hospital, Paddington, London, England, in 1989 and having established the museum in 1993.He was Chairman of the London Museums of Health \& Medicine from 2001 to 2004. He is an authority on Alexander Fleming and the history of penicillin. Brown's 2004 biography of Alexander Fleming, Penicillin Man: Alexander Fleming and the Antibiotic Revolution tells the story of the discovery of penicillin, 2004. The author thanks Kevin Brown for the opportunity to talk about medical museums in London and for a visit to Alexander Fleming Laboratory Museum. 


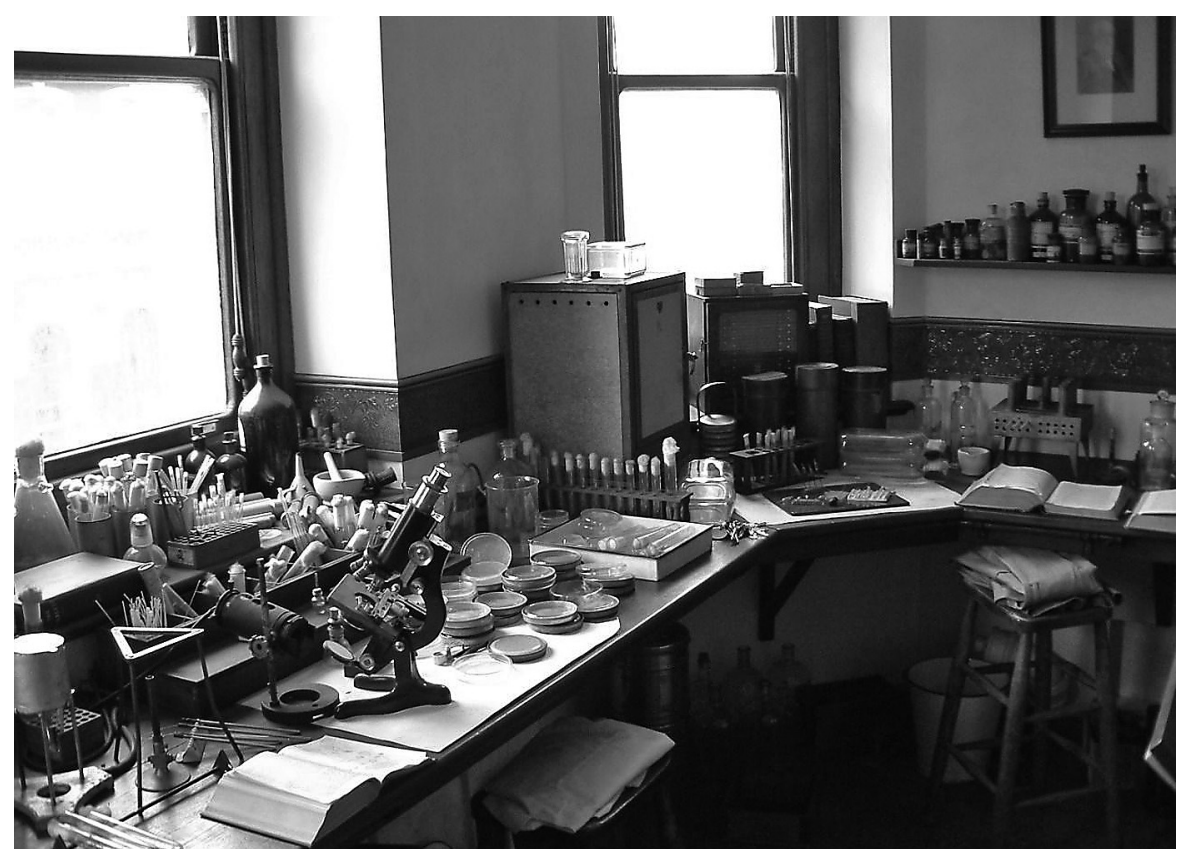

Fot. 2. The Alexander Fleming Laboratory Museum

Source: http://medicalmuseums.org/museum/alexander-fleming-laboratory-museum/ [access on: 15.11.2017].

The exhibition also gives a chance to see the dramatic impact penicillin has made, and to consider the incalculable debt we owe to Sir Alexander Fleming and the many other dedicated researchers who transformed penicillin from a chance observation to a life-saving medicine.

The focal point in the Alexander Fleming Laboratory Museum is a visit to the laboratory in which Alexander Fleming discovered penicillin, a discovery which was to revolutionise medicine and to have an impact on all our lives. In one small room in the museum has been reconstructed Fleming's laboratory as it would have appeared in September 1928 when he noticed a mould killing the bacteria on a petri dish on his lab bench. The exhibition then tells the story of Fleming, penicillin and its impact. A video presentation on the continuing story of penicillin is complete with the visit in The Alexander Fleming Laboratory Museum. The Alexander Fleming Laboratory Museum has been generously sponsored by SmithKline Beecham, the Special Trustees of St. Mary's Hospital and the Delegacy of St. Mary's Hospital Medical School. The Museum is non-profit making. 
The Alexander Fleming Laboratory Museum was designated an International Historic Chemical Landmark by the American Chemical Society and the Royal Society of Chemistry in 1999. It has received an award for penicillin as the most important health advance in the last century from the Republic of San Marino. In 2000 it received an award from The Times for penicillin as a national millennium treasure.

The Alexander Fleming Laboratory Museum has an active education programme. Visits to

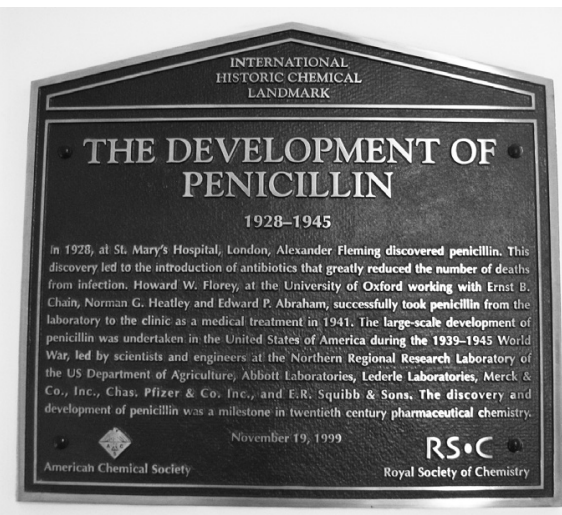

Fot. 3. The chart International Historic Chemical Landmark by the American Chemical Society and the Royal Society of Chemistry

Source: photo: M. Piszczatowska. the Alexander Fleming Laboratory Museum are tailored to the age, ability and interests of educational groups. Staff can visit a school, college, university to talk on such themes within the history of medicine as Fleming and penicillin, hospitals and nursing, the history of bacteriology, antibiotics and the fight against infection, the origins of the National Health Service, bringing along slides and objects to illustrate the talks, presentations and lectures. Educational resource packs are available on Fleming and penicillin and the history of Hospitals and Nursing 1845-1948, healthcare since the mid-nineteenth century and the origins of the National Health Care. ${ }^{5}$

A visit to the Alexander Fleming Laboratory Museum is a kind of walk into the past. The reconstructed laboratory from 1928 is the most important in this exhibition. Visitors have the impression that the person working in the laboratory left it only for a moment.

\section{Nursing is an art}

Florence Nightingale Museum has a completely different character. It celebrates the life and work of the world's most famous nurse. Known as 'The Lady with the Lamp', Florence Nightingale was a pioneering nurse, writer, and noted statistician.

\footnotetext{
${ }^{5}$ http://medicalmuseums.org/museum/alexander-fleming-laboratory-museum/ [access on: 16.11.2017].
} 
Florence Nightingale created modern nursering, contributed to the $19^{\text {th }}$ century everlasting revolution, which changed the role of a woman in society. ${ }^{6}$

The museum is located on the banks of the river Thames opposite the Houses of Parliament. It is situated at a parking level in the grounds of St Thomas' Hospital. The museum was opened in 1989 and now forms a key part of London's medical heritage. To mark the centenary of Florence's death, the museum was modernised and redesigned by the award-winning practice Kossmann.dejong, Amsterdam. ${ }^{7}$ It was re-opened, once again by HRH Princess Alexandra, in May $2010 .{ }^{8}$

The collection consists of personal material associated with Florence Nightingale, items relating to the Crimean War and nursing artefacts. The Florence Nightingale Museum is a peculiar journey through the life of 'The Lady with the Lamp'. The history of Florence Nightingale's life is told in three parts - The Golden Cage - Early life, 1820-1854, The Calling - the Crimean War, 1854-1856, Returning from War - Later life, 1856-1910. In addition, some space in the museum is devoted to Florence Nightingale's Legacy.

The Florence Nightingale Museum has its own website ${ }^{9}$ with a very interesting blog. The blog takes us behind the scenes at the Florence Nightingale Museum, giving fresh insight on everything from discoveries new and old in their collection, to exhibitions, events and learning initiatives. ${ }^{10}$

In Florence Nightingale Museum the visitors discover a woman of many talents - and flaws. Florence was driven and deeply religious. She broke social conventions. She upset friends and family in her determination to improve healthcare for all. Florence Nightingale became a living legend as 'The Lady with the Lamp'. She led the nurses caring for thousands of soldiers during the Crimean War and helped save the British army from medical disaster. This was just one of Florence's many achievements. She was also a visionary health reformer, a brilliant campaigner, the most influential woman in Victorian Britain and its Empire, second only to Queen Victoria herself.

${ }^{6}$ B. Urbanek, S. Duda, Siostra Florencja. Najsłynniejsza pielęgniarka świata, 2.07.2012, „Ale Historia”, tygodnik historyczny, 2012, nr 24, pp. 3-5.

$7 \mathrm{http}$ ://www.kossmanndejong.nl/en/project/florence-nightingale-museum-londen/ [access on: 16.11.2017].

${ }^{8}$ K. Nixon, C. Worthington, Florence Nightingale Museum, London 2010, p. 62.

${ }^{9} \mathrm{http}: / /$ www.florence-nightingale.co.uk [access on: 3.10.2017].

${ }^{10} \mathrm{http}: / / \mathrm{www}$. florence-nightingale.co.uk/blog/?v=9b7d173b068d [access on: 3.10.2017]. 
Kirsteen Nixon ${ }^{11}$ said: “We didn't want to turn it into just a kiddies' museum - although we hope we have included a lot more for them than before, when the museum was just arranged in straight chronological order. We wanted to make sure there was still something for everyone". The museum strikes this difficult balance very well - and it is finely nuanced at other levels too. ${ }^{12}$

Before entering the exhibition we can read the quotes of Florence Nightingale and see her bust. In that part we have also the Florence Nightingale Museum's Wall of Honour. On this Wall there are the names of important people who support the museum.

The first section of the museum is called The Golden Cage - Early life, 1820-1854 and is devoted to Florence's youthful years. The exhibition shows life in the Victorian era and the rules of education for young girls at that time. It also describes the conditions prevailing in hospitals and the level of medicine in the nineteenth century. Hospitals were places where the poor went to die, not places to be cured. Beds were dirty, wards overcrowded and nursing inadequate. People who could afford a doctor and nurse were treated at home. Operations were a last resort. Almost half of a surgeon's patients died from blood poisoning because the importance of hygiene wasn't fully understood. And death in childbirth was an 'expected tragedy' for many women. In 1860's Joseph Lister's use of a fine spray of carbolic acid as an antiseptic dramatically improved patients' survival rates. Pain relief during labour became socially acceptable when Queen Victoria received the new anaesthetic chloroform during the birth of her fourth child in 1853.

Florence and her sister were educated at home, first by governesses and then by their father. They studied French, Latin, German. They took healthy walks daily, visited the local poor with their mother, read Bible, practiced the piano, sang and drew. Her father was teaching Florence maths and statistics which was very useful in her career. $\mathrm{He}$ also supported her financially later in life. Florence grew up in such an environment. Her education was as good as boy's but as a young woman her first duty was to be obedient and make a good marriage.

In this part of the exhibition, we can see souvenirs related to Florence's youth, including furniture, clothes, photos, books. The thread of marriage proposals which Florence received is also raised. Moreover,

${ }^{11}$ Kirsteen Nixon - Collections Manager at Florence Nightingale Museum.

12 https://www.telegraph.co.uk/travel/artsandculture/7710021/Florence-NightingaleMuseum-Shining-a-light-on-the-Lady-with-the-Lamp.html [access on: 3.10.2017]. 


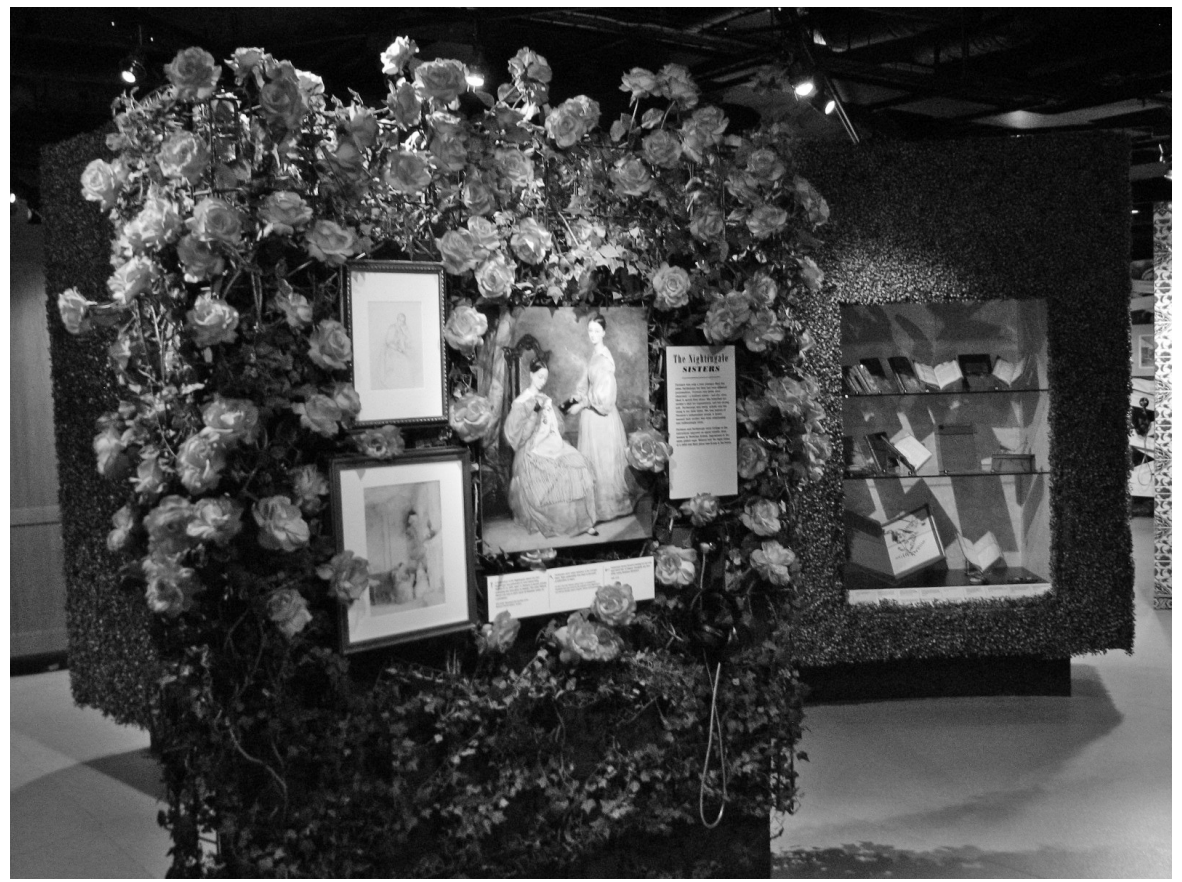

Fot. 4. A fragment of the exhibition The Golden Cage, Florence Nightingale Museum

Source: photo: M. Piszczatowska.

this part of museum is full of memorabilia, from her stuffed pet owl Athens to poetry notebooks and shell collection, the mazelike 'garden' reflects her sense of confinement as she grew up to be a bright, ambitious woman. ${ }^{13}$

The central part there is a bench with the following inscription: On February 7th 1837 God spoke to me and called me to His Service. Florence did not know what her vocation should be for many years. Her Christian faith was the driving force throughout her life. Just before her 17th birthday Florence felt she heard God's 'voice' speaking to her. This happened soon after she had discovered a talent for nursing while caring for her family and their servants during a flu epidemic. She gradually felt that God was calling her to be a nurse - a shocking idea for young women. In the 19th century nursing was not a job for an intelligent, good-looking young woman like Florence. Only working class women nursed for a living.

\footnotetext{
${ }^{13} \mathrm{https}$ ///www.telegraph.co.uk/travel/artsandculture/7710021/Florence-NightingaleMuseum-Shining-a-light-on-the-Lady-with-the-Lamp.html [access on: 3.10.2017]. 
Florence first trained to be a nurse at Keiserswerth near Düsseldorf in Germany. There a protestant pastor Theodore Fliedner and his wife ran a hospital, orphanage and college. There Florence learned about medicines, how to dress wounds, observed amputations and cared for the sick and dying. She had never felt happier. Now I know what it is to live and love life she wrote of the three months she spent there. Then she back to England, her family finally allowed her to nurse. She secured a position at a private care home for 'gentlewoman' in London's Harley Street in 1853.

The second section in the museum is called: The Calling, the Crimean War, 1854-1856 which deals with Florence Nightingale's nursing during the Crimean War, she estimated her patients averaged three limbs each. It is a gritty, striking detail, adding to other information in this well presented, thoughtful revamp.

In March 1854, England and France declared war on Russia, taking the side of Turkey. The Crimean War began. It was the first time when the public could read in the newspapers about how the troops were suffering. More soldiers were dying from disease and from cold during the winter, than from enemy action.

In 1854 , Sidney Herbert, the Secretary of State at War, turned to Florence with the proposal to organize nursing care in hospitals on the front. Florence agreed to organise the nursing expedition. On October 21, 1854, she left London, taking 38 nurses with her, ${ }^{14}$ including 10 Roman Catholic nuns, 14 Protestant nuns, 14 professional nuns. Florence went to Scutari. ${ }^{15}$ The two main military hospitals in Scutari were vast, cold, dirty and stinking at first. The nurses had to cope with long hours and hard physical work - typically washing, sewing and cooking. Experienced woman would dress wounds and change the bandages of the hundreds of often badly injured and frostbitten soldiers. Florence wanted her nurses to be treated with respect by the men and doctors. She also demanded obedience, hence the importance of the uniform and the Scutari sash to identify them as separate from camp followers. Eleven nurses did not return from Scutari. They died from the diseases that also decimated the troops and killed several military doctors. Florence and the doctors at Scutari did not realise that the hospital was on a top of a huge cesspool. In March 1855 Dr John Sutherland, Scottish engineer and his team flushed out the sewers, repaired the building and supplied clean water. Only then did

${ }^{14}$ W. Szenajch, Trzy pielegniarki, Warsaw 1959, p. 25.

${ }^{15}$ Scutari, a suburb of Constantinople, now Üsküdar, Istanbul, 


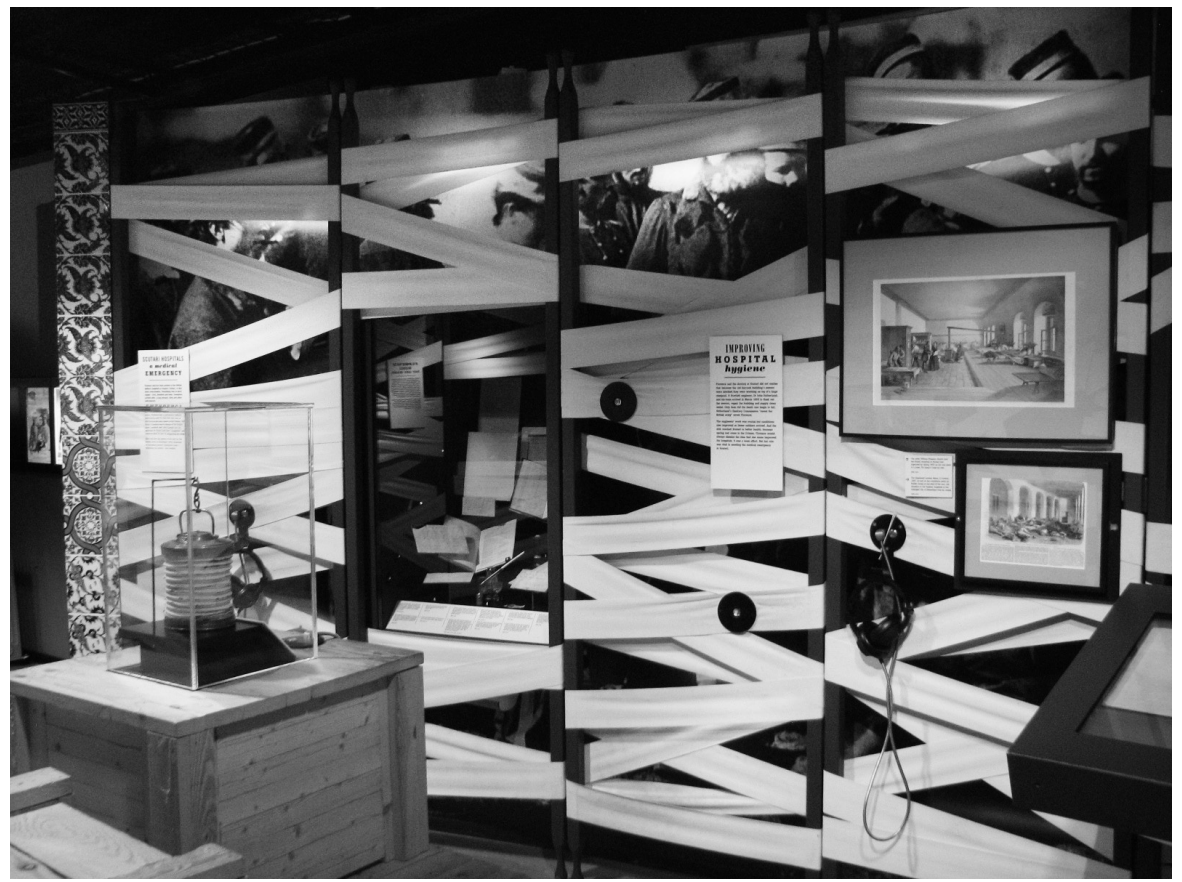

Fot. 5. A fragment of the exhibition The Calling, Florence Nightingale Museum

Source: photo: M. Piszczatowska.

the death rate begin to fall. Sutherland's Sanitary commission saved the British army wrote Florence. ${ }^{16}$

This part of the exhibition was built from connected longitudinal wooden elements, girded with stripes of white material - they refer to the stretcher. In the central part of the exposure visitors can see a Turkish lantern just like the one Florence used to light her nighttime walks around the hospital in Scutari. The image of her holding such a lamp gave rise to the legend of 'The Lady with the Lamp'. In this part we can see, among others, Florence medicine chest where everything is perfectly presented and a typical label says simply e.g.: cough pills, Register of Nurses which is one of the most important documents in the museum - this is the list of all the women who went to nurse at the British military hospitals during the Crimean war under Florence Nightingale. The Register is the first document of nursing

${ }^{16} \mathrm{~J}$. Shepherd, The Crimean Doctors. A history of the British medical Services in the Crimean War, vol. 2, Liverpool 1991, p. 399. 


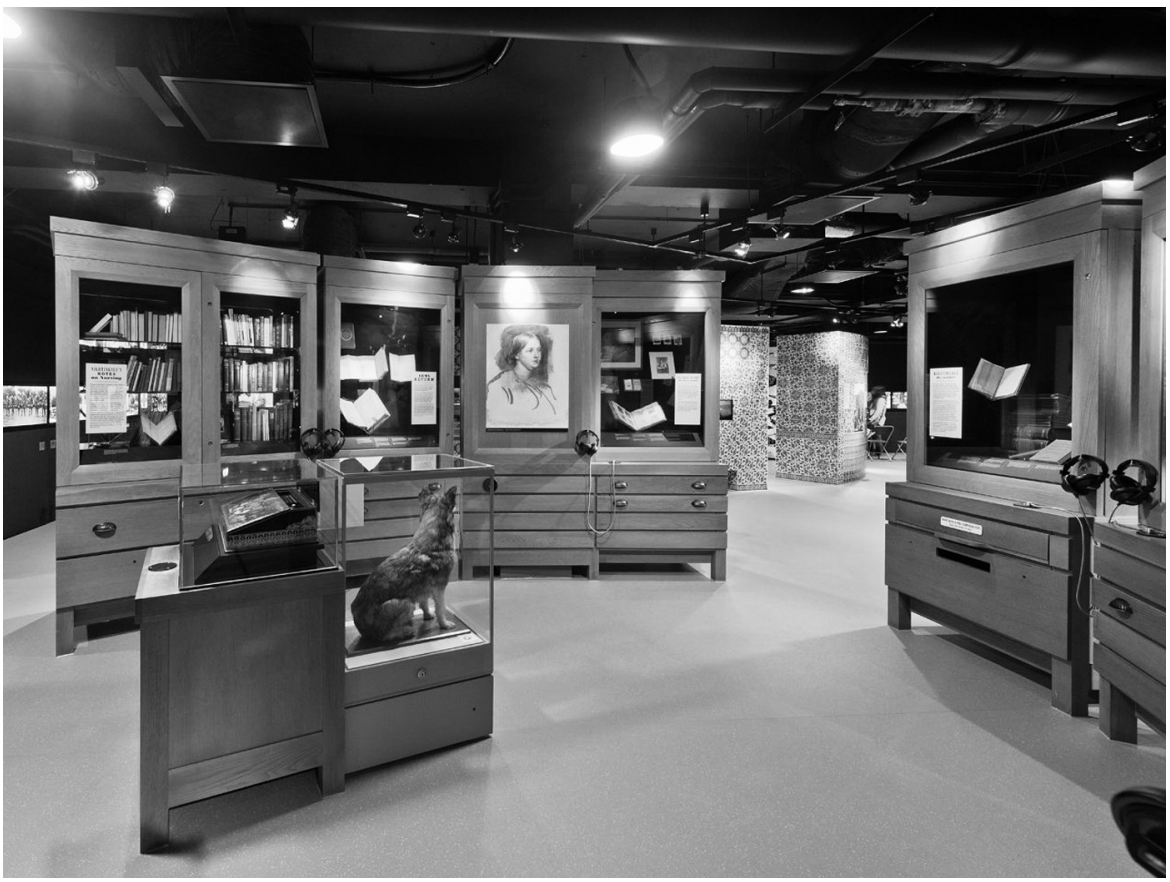

Fot. 6. Part of the exhibition Returning from War, Florence Nightingale Museum

Source: http://medicalmuseums.org/wp-content/uploads/2016/05/from-behind-jack-2. jpg [access on: 15.11.2017].

history and social history. There is some information about nurses: names, age, addresses, where the nurses were from, how long they served, lived or if they died during their service. The Register is now an interactive exhibit, all was scanned and put to computer.

The third and final section of the museum is Returning from War, (Reform and Inspire), Later life, 1856-1910. This is arranged around some Victorian furniture to represent the later, post-Crimean stage of Florence Nightingale's life. Living in London, she herself and her collaborators worked tirelessly. Florence shrank from public appearances, but she skillfully used her reputation and the authority of her name to convince those in power, starting with Queen Victoria, of the need for health reform.

In this part of the museum we can acquaint with Florence's letters, among others, Notes on Nursing, which she wrote to help ordinary women care for their families. Published in January 1860, it became a bestseller. 
Jolyon Attwooll wrote: "Florence Nightingale sparked a revolution in health care that was waiting to happen (prior to the Crimea, British women had not served in military hospitals). But the museum also leaves the impression that it was more than just a case of her being in the right place at the right time. Her combination of intellect, fierce sense of vocation (fuelled by her religious faith), and her well-connected family background, meant perhaps that only Florence Nightingale could have shaped the nursing profession so effectively in that era" ${ }^{17}$

In all parts of the exhibition you can see images by small peepholes. A kind of attraction are also audio points with headphones, where we can hear stories from Florence's life or information about exhibits.

Museum Florence Nightingale has education programme. School groups visit the museum, guided by a costumed 'Florence Nightingale', and the new redesign can only enhance its appeal. The museum also has a corner where the youngest can get to know the people of the Crimean war - the Chef, the Soldier and the Nurse.

Seven years after re-opening Florence Nightingale Museum is very interesting for visitors, the exhibition solutions used there have not lost their attractiveness. The role of Florence Nightingale Museum in the sphere of nursing, education and the creation of culture is indisputable. To be modern and attractive to young visitors, Florence Nightingale Museum makes changes in the way of both the exhibition presentation and also constantly developing museum education. Of great importance there is to offer a multimedia character of the museum exhibition, offering various educational activities on the basis of an active participation strategy, providing a high degree of interactivity and the principle of 'hands-on'.

London is one of the most important centres of medical museology in the world. Over 26 medical museums give the capital of Great Britain priority in this peculiar world of medical museums. Great Britain is also the capital of medical discoveries and great people of medicine. In London's medical museums you can see the original tools of the pioneers of British medicine. London's empire of medical museums is worth knowing.

The author would like to thank The Robert Anderson Research Charitable Trust and Howard Davies, Hon. Secretary for help and care during her stay in London.

\footnotetext{
${ }^{17} \mathrm{https}$ ://www.telegraph.co.uk/travel/artsandculture/7710021/Florence-NightingaleMuseum-Shining-a-light-on-the-Lady-with-the-Lamp.html [access on: 17.11.2017].
} 